\title{
The Relationships Between Managerial Overconfidence, Audit Committee, CEO Duality and Audit Quality and Accounting Misstatements
}

\author{
Nadiah Amirah Nor Azhari ${ }^{1}$, Suhaily Hasnan ${ }^{1} \&$ Zuraidah Mohd Sanusi ${ }^{2}$ \\ ${ }^{1}$ Faculty of Accountancy, Universiti Teknologi MARA, Shah Alam, Selangor, Malaysia \\ ${ }^{2}$ Accounting Research Institute (ARI), Universiti Teknologi MARA, Shah Alam, Selangor, Malaysia \\ Correspondence: Nadiah Amirah Nor Azhari, Faculty of Accountancy, Universiti Teknologi MARA, Shah Alam, \\ Selangor, Malaysia. E-mail: nadiahamirahnorazhari@gmail.com
}

Received: March 16, 2020

Accepted: April 30, 2020

Online Published: June 29, 2020

doi:10.5430/ijfr.v11n3p18

URL: https://doi.org/10.5430/ijfr.v11n3p18

\begin{abstract}
This paper discusses the relationships between managerial overconfidence, financial distress, audit committee, CEO duality and audit quality and the occurrence of material accounting misstatements by Malaysian listed companies. Managerial overconfidence and financial distress are viewed as motives for accounting misstatements in this study. Audit committee characteristics, i.e., independence and expertise of its members, CEO duality and audit quality are viewed as the 'loopholes' in corporate governance mechanisms that provide opportunities for proprietors to issue accounting misstatements. The sample for this study consists of 237 Malaysian listed companies, which includes data from misstated company reports with its respective matched data of non-misstated company reports. The results of this study show that financial distress and CEO duality are significantly related to the occurrence of accounting misstatements. This paper contributes to the body of knowledge on how to mitigate accounting misstatements, especially with the inclusion of the managerial overconfidence variable, which is a new addition to the research on accounting misstatements in Malaysia.
\end{abstract}

Keywords: accounting misstatements, restatement, managerial overconfidence, corporate governance

\section{Introduction}

The International Federation of Accountants (IFAC) (2009) defines accounting misstatement as the dissimilarities between the representation of the reported financial statement items and the representation required by the applicable financial reporting framework. Prior studies have interpreted accounting misstatement as manipulation of financial statement disclosure that does not comply with the current established accounting framework and does not fairly present the firm's financial condition (Dechow et al., 2011). Regardless of the reasons behind a misstatement, be it due to errors or irregularities, any misreported financial information is deemed to be an accounting misstatement (Hennes, Leone, \& Miller, 2008; Hussain, Hasnan, \& Sanusi, 2014; Shibano, 1990).

When an accounting misstatement is discovered and deemed to be material, a restatement will be issued to correct the misstatement. Therefore, the terms, 'restatement' and 'misstatement' are used interchangeably throughout this study (Abbott, Parker, \& Pet, 2004; Mohamed Hussain et al., 2016). Financial restatement is defined as correction of the non-compliance to the Generally Accepted Accounting Principles (GAAP), in terms of recognition, measurement and disclosure of amounts stated in the previous financial statement (Abdullah, Mohamad Yusof, \& Mohamad Nor, 2010; Efendi, Srivastava, \& Swanson, 2007).

The United States (US) General Accounting Office (GAO) reported a total of 2,705 restatements from 1997 to 2006 (GAO, 2002, 2006) and 6,436 for the fiscal years of 2005 through to 2011 (GAO, 2013). Throughout the years, the number of material accounting misstatements has shown fluctuations, sometimes up and sometimes down. Nonetheless, it is a worrisome trend as besides causing significant economic consequences, it also causes public scrutiny of the accounting profession, specifically auditors, in ensuring the quality of financial reporting. The Securities Exchange Commissions (SEC) views a misstatement as an indicator of improper accounting (Romanus, Maher, \& Fleming, 2008). This occurrence, along with the considerable losses it brings to investors and stakeholders, has resulted in a loss of public trust on the credibility of financial reporting, even if the restatement is not due to 
fraudulent behavior (Chen, Elder, \& Hung, 2014).

Even though Malaysia has not kept proper records of accounting misstatements, reports on misstatement scandals reported by the Securities Commission (SC) Malaysia, are available (i.e., Trive Property Group Berhad, YFG Berhad and Multi Sports Holdings Berhad), which is an indication of grave concern (Saieed, 2016; Securities Commission Malaysia, 2018). The increasing number of misstatement cases might due to the weak enforcement by regulators and the absence of proper monitoring mechanisms in companies. The state of the enforcement now appears to be rather lenient as the penalties imposed on these proprietors are not commensurate with the economic consequences of these misstatements (Verschoor, 2014). Further, not only is it inadequate, the penalties are only imposed on a firm that has been found guilty of fraudulent misstatement while other firms have only to restate. Although proven guilty of fraudulent misstatement, such firms are still listed on Bursa Malaysia and can continue their operations. Without adequate punishment, it will be difficult to curb misstatement and the public would be doubtful of the reliability of financial reporting of these firms and its regulators.

Therefore, despite the fact that corporate regulations and accounting frameworks in Malaysia adhere to the international standards, the presence of misstatement cases and poor penalties imposed show that there are loopholes in enforcement. Unless stricter penalties are imposed and more stringent regulations as well as an effective monitoring mechanism are implemented, misstatements will continue and the credibility of financial reporting would be lost. This provides reasonable justification for this study to determine the causes of accounting misstatements in Malaysia.

There are several studies on the issue of accounting misstatement in developed countries; however, research to identify the reasons for the occurrence of accounting misstatement is still limited, especially in developing economies (Lau \& Ooi, 2016). Only a few studies on accounting misstatement have been carried out in developing countries in Asia, such as in Malaysia (Abdullah et al., 2010; Hasnan \& Hussain, 2015; Wahab, Gist, \& Majid, 2014). As the regulations, culture, corporate settings, legislations and financial reporting quality of each nation are unique, differences in findings can be expected, especially when comparing developed and developing countries. Prior researchers, such as also Dechow et al. (2011) and Abdullah et al. (2010) have suggested that the causes for accounting misstatement may differ between countries. Therefore, this study contributes new information for further research on material accounting misstatement in a developing country, such as Malaysia.

To help mitigate the issue of material accounting misstatements, this study examined the motives and opportunities that could contribute to the occurrence of material accounting misstatements in Malaysia. Since the litigation costs of corporate offences are quite high, offenders must possess a strong motive and the right opportunity to commit the offence. The motives for the occurrence of material accounting misstatement for this study are examined from the context of managerial overconfidence and financial distress, which are believed to influence a firm's judgment and increase the pressure on the firm to issue a material accounting misstatement. The US GAO (2002) believes that accounting misstatement, to a certain extent, reflects the weakness of corporate governance mechanisms. As a firm's control and monitoring mechanisms, corporate governance was examined in this study, to determine whether or not its weaknesses, in terms of its audit committee, the existence of Chief Executive Officer (CEO) duality and audit quality, could provide an opportunity for material accounting misstatements to occur.

The paper is organised as follows. Section 2 describes hypotheses development, followed by Section 3 which discusses the research methodology. The subsequent section discusses the results of the study, and the paper concludes in Section 5 .

\section{Hypotheses Development}

Jensen and Meckling (1976) defined an agency relationship as a contract under which one or more persons (the principal(s)) engage another person (the agent) to perform some service on their behalf which involves delegating some decision-making authority to the agent. However, both principal and agent are utility maximisers and want to act for their own best interests (Shleifer \& Vishny, 1989). Denis (2001) illustrated that to remain in power, managers may be inclined to engage in misstatement and fraud. The inability of shareholders to supervise all decisions made, provides the opportunity for opportunistic actions (Fama, 1980). In any fraudulent act, there must be motives and opportunities to commit it. Hence, in this study, motives (i.e., managerial overconfidence and financial distress) and opportunities (i.e., weak corporate governance mechanisms, or audit committee characteristics, CEO duality and audit quality) are used as indicators of the occurrence of material accounting misstatements.

\subsection{Managerial Overconfidence and Accounting Misstatements}

Overconfidence is defined as an unrealistic belief on an uncertain outcome by underestimating the probabilities of a negative outcome (Schrand \& Zechman, 2008). It could cause managers to have unrealistic optimism of the company's 
future performance and underestimate any influence of unexpected events that could negatively affect corporate decision-making (Hribar \& Yang, 2016; Malmendier \& Tate, 2005). However, there are arguments that suggest overconfidence is desirable in corporate settings as it allows firms to be more competitive and better innovators (Brunnermeier \& Parker, 2005; Compte \& Postlewaite, 2004; Galasso \& Simcoe, 2010; Gervais \& Goldstein, 2007).

Overconfidence can lead managers to utilise aggressive accounting techniques to forecast earnings, that in turn, could lead to unreasonable forecasts (Hribar \& Yang, 2010) and distorted financing and investment decisions to be made (Lomwel, 2018; Zhao \& Ziebart, 2017). Eventually, if the firm's judgments are not met and to avoid being labeled as incompetent, accounting misstatement would be viewed as an option. This is especially so when overconfident managers have higher idiosyncratic risks as they have more invested wealth in the firm's shares and their reputation and employability rely on the firm's performance (Barros \& da Silveira, 2007; Gilson, 1989; Park \& Chung, 2017).

Therefore, managerial overconfidence would eventually lead to an optimistically-biased financial reporting statement (Merrienboer, 2016), when the expectation from the over-optimistic judgment does not come through (Schrand \& Zechman, 2008). Presley and Abbott (2013) found a significantly positive relationship when they examined the association between overconfidence and accounting misstatement. Schrand and Zechman $(2008,2012)$ also found that misreporting firms exhibit overconfidence compared to firms without misstatements. Their studies show that the accounting misstatement is due to earnings management done to meet the overoptimistic forecast earnings, which usually starts as a small amount and escalates to a bigger amount that causes the overconfident manager to materially misstate the financial statement in order to conceal the truth about the firm's financial performance.

In Malaysia, there are no studies on this particular area. Prior studies on managerial overconfidence in Malaysia have mostly been related to corporate debt or leverage decisions (Purhanudin \& Zakaria, 2015; Ting et al., 2016; Wei et al., 2015). However, other prior studies' findings that have associated managerial overconfidence with conservative accounting (Ahmed \& Duellman, 2013); overoptimistic bias in earnings forecast (Schrand \& Zechman, 2012); financial restatement (Presley \& Abbott, 2013); and earnings management (Malmendier \& Tate, 2015), provide sufficient justification for its relationship with the occurrence of material accounting misstatement.

Therefore, the hypothesis is as follows:

H1: There is a significant relationship between managerial overconfidence and the occurrence of material accounting misstatement.

\subsection{Financial Distress and Accounting Misstatements}

Financial distress is an insufficient state of cash flow that causes firms' failure to meet current financial obligations (Khaliq, Motawe Altarturi, Mohd Thas Thaker, Harun, \& Nahar, 2014; Wruck, 1990). It is detrimental both to the firm and its management. Financial distress causes firms to decrease in value; it affects operational efficiency and performance and threatens the management's position and reputation (Khaliq et al., 2014). If firms cannot withstand the pressure and bear the costs, the firms might be forced into liquidation or bankruptcy (Khaliq et al., 2014; Pandey, 2005). These adverse effects might motivate managers to commit accounting misstatements in order to mask their current situation from public knowledge (Desai, Hogan, \& Wilkins, 2006). It motivates the firm managers to fraudulently improve the appearance of the firms' financial condition by "cooking the books" (Firth, Rui, \& Wu, 2011; Spathis, 2002).

Extant literature supports the relationship between financial distress and accounting misstatement (Beasley, 1996; Hasnan, Abdul Rahman, \& Mahenthiran, 2013). Arshad, Iqbal, and Omar (2015) and Firth et al. (2011) also found that business failure or financial distress contributes to fraudulent accounting statements, as distressed firms are the most likely to commit this fraudulent act. A firm would issue a misstatement to secure business opportunities (Khaliq et al., 2014); avoid debt covenant violations (DeFond \& Jiambalvo, 1994); and also avoid delisting by the stock exchange (Chen, Chen \& Huang, 2010). The manipulation is also done by distressed firms to secure a position in the corporate market (Beasley, 1996). With their position and reputation at stake, managers may be motivated to conceal the deteriorating performance by resorting to misstatement (Habib et al., 2013; Persons, 1995).

Thus, the hypothesis is as follows:

$\mathrm{H} 2$ : There is a significant relationship between financial distress and the occurrence of material accounting misstatement.

\subsection{Audit Committee Independence}

One of the major roles of the audit committee is to oversee the efforts to produce a fair financial statement by resolving any conflicts between external auditors and the firm's management. Thus, it is important for its members to be 
independent (Klein, 2002). The Bursa listing requirements require that all audit committees mainly consist of independent members (Bursa Malaysia, 2018). If a member of the audit committee is part of the firm's executive team, his or her independence in overseeing the firm's reporting process would be reduced as he or she will be bound by the management's decisions (Abdullah et al., 2010). Therefore, to ensure the quality of financial reporting, it is best to have an independent audit committee.

Abbott et al. (2004) and Mohd Saleh et al. (2007) found that an independent audit committee could reduce the presence of earnings management and fraudulent accounting misstatements, as its members are not bound by the interests of the firm's management. In the event of misstatement, the reputation and integrity of the independent members would be questioned, and thus, it is believed that the members would carry out their duties effectively (Abdullah et al., 2010) and demand greater audit scope to ensure the financial statements are free from accounting misstatement, thus supporting the findings of prior studies that an independent audit committee is negatively related to the occurrence of accounting misstatement (Abbott et al., 2004).

However, some prior studies have not found that having an independent audit committee contributes to effective monitoring of the firm's governance (Abdullah \& Mohd. Nasir, 2004; Mohd Saleh et al., 2005). Baber, Kang, and Liang (2005) also found that audit committee independence does not mitigate accounting misstatement, which shows that having an independent audit committee is not a guarantee of effective monitoring of the firm's reporting credibility.

Hence, the hypothesis is as follows:

H3: There is a significant relationship between audit committee independence and the occurrence of material accounting misstatement.

\subsection{Audit Committee Expertise}

The Malaysian Code of Corporate Governance (2017) states that it is preferable for the audit committee members to have financial knowledge and expertise to help monitor the firm's financial reporting process (Securities Commission Malaysia, 2017c). Managers who are supervised by expert audit committee members tend to carry out lesser earnings management practices (Dhaliwal, Naiker, and Navissi, 2010; Mohd Saleh et al., 2007). The presence of financial experts in the audit committee also helps to improve the cooperation between the audit committee and the firm's auditors, thus helping to maintain higher audit quality and producing a credible financial statement (Nelson and Devi, 2013; Ghafran and O'Sullivan, 2017).

A study done on audit committee characteristics in Malaysia by Wan Mohammad et al. (2018) has found that audit committee expertise reduces the likelihood of financial restatement. Other studies also support the finding as it has been found that the presence of financial experts in the audit committee can improve accounting quality and mitigate the occurrence of accounting misstatement (Agrawal \& Chadha, 2005; Bedard, Chtourou, \& Courteau, 2004; Shin, Xu, Lacina, \& Zhang, 2014).

However, the findings on the relationship between the audit committee with financial expertise and accounting misstatement are mixed. A prior study has found that having members with financial expertise in the audit committee does not contribute to the audit committee effectively curbing earnings management (Zahn \& Tower, 2004). Therefore, based on the above findings, this study hypothesises that:

H4: There is a significant relationship between audit committee expertise and the occurrence of material accounting misstatement.

\subsection{CEO Duality}

It is recommended by the MCCG (2017) that the positions of the Board Chairman and the CEO be separated to ensure proper governance (Securities Commission Malaysia, 2017c). Drobetz, Schillhofer, and Zimmermann (2004) and Jensen (1993) found that CEO duality motivates the individual to act for his/her own interests instead of maximising the shareholders' wealth, which is supported by the agency theory. Although, there are studies that have found that the CEO, as a steward, would act in the interests of shareholders (Davis et al., 1991, 2000; Martin \& Butler, 2017), having both governance and management power would allow the individual to manipulate the agenda of the board meeting according to his/her own best interests, which would then prevent fair disclosure (Abdullah, 2004).

Prior studies have found that CEO duality is positively associated with earnings management, fraudulent reporting and poor earnings quality (Byard, Li, \& Weintrop, 2006; Dechow et al., 1996). It has also been linked to financial restatement, which indicates that duality weakens the corporate governance structure that is supposed to prevent accounting misstatement (Efendi et al., 2007). This supports the opinion of the authority received from CEO duality is 
misused for personal gain and to protect the individual's own interests, thus contributing to accounting misstatement. Therefore, separating the positions of the CEO and the board chairman is crucial to obtain more effective monitoring and governance structure (Hasnan et al., 2017).

The next hypothesis is as follows:

H5: There is a significant relationship between CEO duality and the occurrence of material accounting misstatement.

\subsection{Audit Quality}

The firm's management is responsible for preparing the financial statement that fairly reflects the firm's current financial position to help users in their decision-making. However, to ensure the credibility of the financial statement, there must be proper governance. This is where the external auditors execute their role in ensuring the financial statement presents a true and fair view (Alabede, 2012). The role of the external auditors is crucial as they safeguard the investors and shareholders' interests from insider expropriation (Newman, Patterson, \& Smith, 2005).

Malaysia's big four audit firms are Deloitte, KPMG, Ernst \& Young (EY) and PricewaterhouseCoopers (PWC). Prior researchers have found that big four auditors demonstrate higher audit quality (DeAngelo, 1981; DeFond \& Jiambalvo, 1993). It has been shown that big four audit firms are more competent than other firms (Watts \& Zimmerman, 1981). As big four audit firms have a higher reputation, they have a greater economic interest to provide reasonable assurance that the financial statement that they have audited is free from material errors as any misstatement disclosed for any financial year that they have audited would negatively affect them (DeFond and Jiambalvo, 1991).

The capabilities of big four auditors could be seen in prior findings that have indicated that hiring big four auditors could lower the litigation rate and curb earnings management practices compared to hiring non-big four auditors (Becker et al., 1998; DeFond \& Jiambalvo, 1991). Zhizhong et al. (2011) found that misstatement could be mitigated by hiring strong external auditors from big four audit firms. Nevertheless, other studies have shown that there is no relationship between big four auditors' audit quality and their credibility in curbing earnings management (Yasar, 2013). This study hypothesizes that:

H6: There is a significant relationship between audit quality and the occurrence of material accounting misstatement.

\section{Research Methodology}

\subsection{Sample Formation}

The sample of this study comprises companies listed on the Bursa Malaysia main market from 2011 to 2017, excluding companies listed under the financial sector. The occurrence of material accounting misstatement is measured using financial restatement. As Malaysia does not have available established records of restatement, manual collection through Bursa Malaysia's listed annual reports was done. To detect whether or not there is restatement in the annual reports, the keywords of "restatement", "restate", "restated", "comparative figure" or "prior year adjustments", were searched in each annual report to find any evidence of restatement (Abdullah et al., 2010; Hasnan, Marzuki, \& Shuhidan, 2017).

As there is an absence of proper guidelines to determine material accounting misstatement in Malaysia, the GAO's financial restatement category description was used to determine the sample for this study and misstatements caused by the changes in accounting principles, minor errors and misinterpretations of accounting rules were excluded. Matched-pair procedures were used to form a control group, comprising two non-restating firms, with matched total assets and without matched total assets. These sample formation procedures were necessary to ensure a more comprehensive sample formation. A total of 237 samples that included 79 restatement samples and 158 non-restatement samples were finalised for this study.

\subsection{Variables Measurement}

The source for this study's data is mainly from firms' annual reports as disclosed on the Bursa Malaysia website. Figure 1 illustrates the timeline for data collection for proxies that represent each variable. The data for this study was collected one year prior to the material accounting misstatement incidents (labeled as " $t-1$ "). For example, if the restatement was announced in 2010 (n) to restate the misstatement made in 2008 (t), the data collected was from 2007 (t-1) annual reports of the restating firms, matched with non-restating companies' (control firm) information for the same year. This is based on the findings by Dechow et al. (2011) that misstating firms actively manipulate their statements before and during the misstatement event period. 


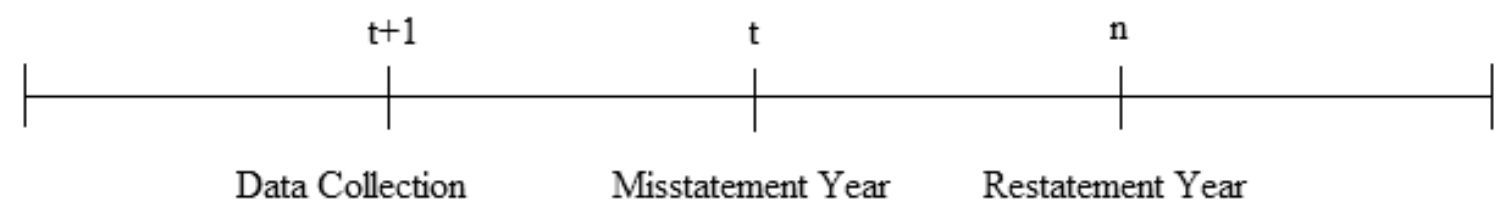

Figure 1. Timeline for data collection

\subsubsection{Dependent Variable}

Referring to prior studies on accounting misstatements in Malaysia, the occurrence of material accounting misstatements, proxied by financial restatements, was measured using a dummy variable, coded as " 1 " for restating companies, and " 0 " for non-restating companies (Abdullah et al., 2010; Aziz, Mohamed, \& Hasnan, 2017; Hasnan \& Hussain, 2015; Hasnan et al., 2017).

\subsubsection{Independent Variables}

The independent variables for this study are the motives and opportunities that led to the occurrence of the material accounting misstatements. The motives are managerial overconfidence and financial distress. Managerial overconfidence was proxied by the firm's capital structure variable using debt to equity ratio (Malmendier, Tate, \& Yan, 2011; Schrand \& Zechman, 2012). It was measured by total debt divided by the firm's total market value from the sum of equity and book value of long-term debt and preferred stock. The ratio was compared to the industry median for the financial year, and if the value was higher, it meant overconfidence existed, and a dummy variable was used and coded " 1 " or " 0 ", otherwise.

Financial distress was measured by using Altman Z-Score, which has been used in prior studies on it's viability to measure the level of financial distress (Gul et al., 2018; Hennes et al., 2008). Altman Z- Score means that firms with a score of less than 2.073 are assumed to be in financial distress; thus, a dummy variable was used and coded as " 1 " for a score below $2.073(<2.073)$ and "0" otherwise.

The Z-Score was calculated by using the formula prescribed by Altman (1968):

$$
\mathrm{Z}=1.2 \mathrm{X}_{1}+1.4 \mathrm{X}_{2}+3.3 \mathrm{X}_{3}+0.6 \mathrm{X}_{4}+1.0 \mathrm{X}_{5}
$$

Where:

$\mathrm{X}_{1}$ : Working capital to total assets

$\mathrm{X}_{2}$ : Retained earnings to total assets

$\mathrm{X}_{3}$ : Earnings before interest and taxes to total assets

$\mathrm{X}_{4}$ : Market value of equity to total liabilities

$\mathrm{X}_{5}$ : Net sales to total assets

The opportunities for the occurrence of material accounting misstatement examined in this study consist of audit committee independence, audit committee expertise, CEO duality and audit quality. The independence of the audit committee was determined from the percentage of independent audit committee members in the committee (Ghafran \& O’Sullivan, 2017; Poretti, Schatt, \& Bruynseels, 2018).

Audit committee expertise was measured from the proportion of audit committee members with financial expertise. The expertise recognised in this study included the members' qualifications or experience in accounting, and membership in professional accounting bodies (Ghafran \& O'Sullivan, 2017; Zalata, Tauringana, \& Tingbani, 2018).

The firm was presumed to have practiced CEO duality if the firm's CEO also held the post of chairman of the firm's board. A dichotomous variable was used, and coded as " 1 " if the posts of board chairman and CEO were combined, and "0", otherwise (Su, 2010; Zhou et al., 2018).

External auditors from the big 4 audit firms is the proxy for audit quality for this study; a dummy variable was used, and coded as " 1 " if the auditor is a Big 4 auditor, and " 0 ", otherwise (Abid, Shaique, \& Anwar ul Haq, 2018; Zalata et al., 2018). 


\subsection{Model and Data Analysis}

To test the hypotheses generated in this study, the data collected was analysed using IBM SPSS Statistics 23. Pearson correlation was used to test the statistical association between two of the variables tested. To test the relationships between multiple variables and the occurrence of accounting misstatement, binary logistic regression models was used. The logistic regression model generated below was tested to determine the relationships and the effect of those variables on the occurrence of accounting misstatements.

$\mathrm{FR}=\beta_{0}+\beta_{1} \operatorname{MOCi}(\mathrm{t}-1)+\beta_{2}$ DISTRESSi (t-1) $+\beta_{3}$ ACINDi (t-1) $+\beta_{4} \mathrm{ACEi}(\mathrm{t}-1)+\beta_{5}$ DUALi (t-1) $+\beta 6 \mathrm{BIG} 4 \mathrm{i}(\mathrm{t}-1)+\varepsilon \mathrm{i}(\mathrm{t}-1)$

Where:

$\begin{array}{ll}\text { FR } & : \text { Financial restatement } \\ \text { MOC } & : \text { Managerial overconfidence } \\ \text { DISTRESS } & : \text { Financial distress } \\ \text { ACIND } & : \text { Audit committee independence } \\ \text { ACE } & : \text { Audit committee expertise } \\ \text { DUAL } & : \text { CEO duality } \\ \text { BIG4 } & : \text { Big } 4 \text { audit firms }\end{array}$

4. Results and Discussions

Table 1. Pearson correlation matrix of independent variables

\begin{tabular}{lrrrrrrr}
\hline & \multicolumn{1}{c}{ FR } & \multicolumn{1}{c}{ MOC } & DISTRESS & ACIND & ACE & DUAL & BIG4 \\
\hline FR & 1 & & & & & & \\
MOC & .048 & 1 & & & & & \\
DISTRESS & $.204^{* *}$ & $.502^{* *}$ & 1 & & & & \\
ACIND & .048 & -.022 & -.080 & 1 & & & \\
ACE & .092 & .030 & .055 & .085 & 1 & & \\
DUAL & .119 & $-.132^{*}$ & -.119 & .071 & .068 & 1 & \\
BIG4 & -.018 & -.012 & .017 & -.078 & -.068 & $-.184^{* *}$ & \\
\hline
\end{tabular}

Notes: All p-values are 2-tailed. *Correlation is significant at the 0.05 level; and **Correlation is significant at the 0.01 level.

The statistical results above show the correlation between all the independent variables and the dependent variable. Table 1 shows that there are four significant correlations, of which three are at the $1 \%$ level, while one is at the $5 \%$ level. In the book of Pallant (2016), Cohen (1988) suggests that a correlation that is higher than 0.5 is interpreted as having a large correlation. However, the presence of severe collinearity is only a concern if the correlation is more than 0.8 , i.e., the threshold set by Cooper and Schindler (1998). Thus, none of the variables in this study was excluded.

Table 1 above shows that there is a highly significant and positive correlation (above 0.502) between managerial overconfidence (MOC) and financial distress (DISTRESS) at the $1 \%$ level. It shows that the presence of managerial overconfidence is associated with the occurrence of financial distress. This means that managerial overconfidence might lead firms to financial distress as reported by Hackbarth (2008) that overconfidence tends to lead to higher debt, that eventually contributes to financial distress.

The result also shows that there is a significantly positive correlation (0.204) between financial distress (DISTRESS) and the occurrence of material accounting misstatement (FR). This is consistent with the findings of prior literature that financial distress would motivate the issuance of accounting misstatement (Firth et al., 2011; Hasnan et al., 2013).

There is also a significantly negative association although of low correlation (-0.132) between managerial overconfidence and CEO duality. Prior studies have not found a negative association between these two variables; however, it is deemed to be insignificant (Khajavi \& Dehghani, 2016). However, there is a study that has found that there is a direct relationship between duality and overconfidence (Koloub \& Shoorvarzy, 2015). 
The other significantly negative correlation (-0.184) is between audit quality, proxied by big four audit firms and CEO duality. The result posits that individuals who hold dual positions in a firm would prefer lower audit quality as it would allow them to act on personal interests (Zanani \& Abdullah, 2008).

Table 2. Logistic regression analysis results

\begin{tabular}{|c|c|c|c|c|c|c|c|c|}
\hline & \multirow[b]{2}{*}{$\mathrm{B}$} & \multirow[b]{2}{*}{ S.E. } & \multirow[b]{2}{*}{ Wald } & \multirow[b]{2}{*}{ df } & \multirow[b]{2}{*}{ Sig. } & \multirow[b]{2}{*}{$\operatorname{Exp}(\mathrm{B})$} & \multicolumn{2}{|c|}{$95 \%$ C.I. for $\operatorname{EXP}(B)$} \\
\hline & & & & & & & Lower & Upper \\
\hline MOC(1) & -.294 & .341 & .740 & 1 & .390 & .746 & .382 & 1.456 \\
\hline DISTRESS(1) & 1.139 & .346 & 10.839 & 1 & $.001 * *$ & 3.122 & 1.585 & 6.150 \\
\hline ACIND & .845 & .974 & .752 & 1 & .386 & 2.328 & .345 & 15.710 \\
\hline $\mathrm{ACE}$ & .660 & .649 & 1.037 & 1 & .309 & 1.936 & .543 & 6.902 \\
\hline DUAL(1) & .830 & .405 & 4.211 & 1 & $.040 *$ & 2.294 & 1.038 & 5.070 \\
\hline BIG4(1) & .040 & .293 & .019 & 1 & .891 & 1.041 & .587 & 1.846 \\
\hline Constant & -2.292 & .965 & 5.641 & 1 & .018 & .101 & & \\
\hline $\mathrm{N}$ & 237 & & & & & & & \\
\hline
\end{tabular}

In this study, $\mathrm{H} 1$ to $\mathrm{H} 6$ predict a significant relationship between motives (managerial overconfidence and financial distress) and opportunities (audit committee independence, audit committee expertise, CEO duality and audit quality) and the occurrence of material accounting misstatement. The results of the logistic regression model are as in Table 2. For the predicted misstatements firms, the model has a $\mathrm{R}^{2}$ value of 9.6 per cent, which means that 9.6 per cent of the variation in the incidence of material accounting misstatements is explained by the variation in the factors studied.

The result indicates that there are two variables which are important determinants of material accounting misstatements. The DISTRESS variable is positively and significantly associated with material accounting misstatement at the $1 \%$ level of significance, while the DUAL variable is positively and significantly associated with the occurrence of material accounting misstatement at the 5\% level of significance, thus supporting hypotheses $\mathrm{H} 2$ and H5.

The results of logistic regression in this study do not provide support for hypotheses H1, H3, H4 and H6, since managerial overconfidence, audit committee independence, audit committee expertise and audit quality, are not significantly associated with material accounting misstatement. The insignificant association between managerial overconfidence and the occurrence of material accounting misstatement shows that managerial overconfidence is not the motivating factor for material accounting misstatement for Malaysian listed companies. However, since the addition of managerial overconfidence as a determinant of accounting misstatement is rather new, more research could be conducted in future using a different measurement to determine if managerial overconfidence might produce different results.

This study also finds that audit committee characteristics (independence and expertise) are not significantly related to the occurrence of accounting misstatement. These results are consistent with prior findings that audit committee independence (Abdullah \& Mohd. Nasir, 2004; Baber et al., 2005) and audit committee expertise (Zahn \& Tower, 2004) are not effective corporate mechanisms as they have failed to curb misstatement.

Audit quality, which is proxied by big four audit firms, also does not have a significant relationship with the occurrence of material accounting misstatement. Even though some studies have found that big four auditors as more competent in ensuring the credibility of the financial statement, this study supports Yasar's (2013) findings that big four audit firms do not contribute to higher credibility of financial reporting.

Financial distress has a significant relationship with the occurrence of material accounting misstatement in this study. This result is consistent with prior research conducted in Malaysia that has found that financial distress motivates firms to participate in accounting misstatement (Hasnan et al., 2013; Hasnan \& Hussain, 2015). The firm's deteriorating financial state provides an incentive for firms to participate in accounting misstatement (Beasley, Carcello, \& Hermanson, 1999; Dechow et al., 2011).

CEO duality also has a positively significant relationship with accounting misstatement. This support hypothesis H5, 
showing that CEO duality indicates that corporate governance is weak and has failed to curb accounting misstatement (Efendi et al., 2007).

\section{Conclusion}

The study examined the relationships between managerial overconfidence, financial distress, audit committee, CEO duality and audit quality and the occurrence of material accounting misstatement. This research contributes to the body of knowledge on the factors that could contribute to accounting misstatement and whether the corporate governance mechanisms tested, i.e., audit committee and audit quality, could act as effective control mechanisms to mitigate accounting misstatement.

As explained above, only two of the variables are significantly related to material accounting misstatement. Financial distress is a motivating factor that contributes to the occurrence of accounting misstatement due to the pressure it exerts on the firm and its management. As for CEO duality, it appears to be a loophole in corporate governance as the findings show that it has a significantly positive relationship with the occurrence of accounting misstatement.

As the financial statement is an important tool for decision-making and misstatements have been proven to be detrimental to the firm and its stakeholders, further research needs to be conducted on the determinants of accounting misstatement in order to curb its occurrence. The present model could be improved by adding variables other than audit committee, CEO duality and audit quality, which could fill the gap mentioned by Dechow et al. (2011) .

Lastly, it is recommended that further studies be done on the relationship between managerial overconfidence and the occurrence of material accounting misstatement. This study did not find any significant relationship between managerial overconfidence and accounting misstatement by using a dichotomous measurement based on debt to equity ratio of the sampled firms compared to the median industry. Therefore, more research could be done by using other measurements to determine the role that managerial overconfidence plays in the occurrence of accounting misstatements.

\section{Acknowledgements}

The authors would like to express their gratitude to the Faculty of Accountancy, Universiti Teknologi MARA for sponsoring their participation in the International Conference on Accounting and Management (ICAM) 2019. The authors would also like to thank the Ministry of Higher Education and Research Management Institute (RMI), Universiti Teknologi MARA for awarding the Prototype Research Grant Scheme (PRGS/1/2017/SS01/UITM/02/1) that provided the financial support for the conduct of this paper.

\section{References}

Abbott, L. J., Parker, S., \& Pet. (2004). Audit Committee Characteristics and Restatements. Auditing: A Journal of Practice \& Theory, 23(1), 69-87. https://doi.org/10.2308/aud.2004.23.1.69

Abdullah, S. N., Mohamad Yusof, N. Z., \& Mohamad Nor, M. N. (2010). Financial restatements and corporate governance among Malaysian listed companies. Managerial Auditing Journal, 25(6), 526-552. https://doi.org/10.1108/02686901011054854

Abdullah, S. N., \& Mohd. Nasir, N. (2004). Accrual management and the independence of the boards of directors and audit committees. IIUM Journal of Economics and Management, 12(1), 1-31.

Abid, A., Shaique, M., \& Anwar ul Haq, M. (2018). Do Big Four Auditors Always Provide Higher Audit Quality? Evidence from Pakistan. International Journal of Financial Studies, 6(2), 58. https://doi.org/10.3390/ijfs6020058

Ahmed, A. S., \& Duellman, S. (2013). Managerial Overconfidence and Accounting Conservatism. Journal of Accounting Research, 51(1), 1-30. https://doi.org/https://doi.org/10.1111/j.1475-679X.2012.00467.x

Alabede, J. O. (2012). The Role, Compromise and Problems of the External Auditor in Corporate Governance *. Research Journal of Finance and Accounting, 3(9), 114-126.

Altman, E. I. (1968). Financial Ratios, Discriminant Analysis and the Prediction of Corporate Bankruptcy. The Journal Of Finance, 23(4), 589-609.

Arshad, R., Iqbal, S. M., \& Omar, N. (2015). Prediction of Business Failure and Fraudulent Financial Reporting: Evidence from Malaysia. Indian Journal of Corporate Governance, 8(1), 34-53. https://doi.org/10.1177/0974686215574424

Aziz, N. F., Mohamed, M., \& Hasnan, S. (2017). Ownership Structure and Financial Restatement in Malaysia. Pertanika Journal of Social Sciences \& Humanities, 25(S), 227-236. 
Baber, W. R., Kang, S. H., \& Liang, L. (2005). Strong boards, management entrenchment, and accounting restatement. European Accounting Association Meetings.

Barros, L. A. B. de C., \& da Silveira, A. D. M. (2007). Overconfidence, Managerial Optimism and the Determinants of Capital Structure. SSRN, 1-33. https://doi.org/10.2139/ssrn.953273

Beasley, M. S. (1996). An Empirical Analysis of the Relation between the Board of Director Composition and Financial Statement Fraud. Accounting Review, 443-465.

Beasley, M. S., Carcello, J. V, \& Hermanson, D. R. (1999). Fraudulent Financial Reporting: 1987-1997 An Analysis of U.S. Public Companies Research. COSO, 1-67.

Becker, C. L., Defond, M. L., Jiambalvo, J., \& Subramanyam, K. R. (1998). The Effect of Audit Quality on Earnings Management. Contemporary Accounting Research, 15(1), 1-24.

Brunnermeier, M. K., \& Parker, J. A. (2005). Optimal expectations. American Economic Review, 95(4), 1092-1118. https://doi.org/10.1257/0002828054825493

Bursa Malaysia. Bursa Malaysia Main Market Listing Requirement (2018).

Chen, K. Y., Elder, R. J., \& Hung, S. (2014). Do post-restatement firms care about financial credibility? Evidence from the pre- and post-SOX eras. Journal of Accounting and Public Policy, 33(2), 107-126. https://doi.org/10.1016/j.jaccpubpol.2013.12.002

Chen, Y., Chen, C.-H., \& Huang, S.-L. (2010). An Appraisal of Financially Distressed Companies' Earnings Management: Evidence from Listed Companies in China. Pacific Accounting Review, 22(1), 22-41.

Compte, O., \& Postlewaite, A. (2004). Confidence-Enhanced Performance. The American Economic Review, 94(5), 1536-1557. https://doi.org/10.2307/3592833

DeAngelo, L. E. (1981, July). Auditor size and audit quality. Journal of Accounting and Economics, 3, 183-199.

Dechow, P. M., Ge, W., Larson, C. R., \& Sloan, R. G. (2011). Predicting Material Accounting Misstatements. Contemporary Accounting Research, 28(1), 17-82. https://doi.org/10.1111/j.1911-3846.2010.01041.x

DeFond, M. L., \& Jiambalvo, J. (1991). Incidence and Circumstances of Accounting Errors. The Accounting Review, $66(3), 643-655$.

DeFond, M. L., \& Jiambalvo, J. (1993). Factors Related to Auditor-Client Disagreements over Income-Increasing Accounting Methods*. Contemporary Accounting Research, 9(2), 415-432.

DeFond, M. L., \& Jiambalvo, J. (1994). Debt covenant violation and manipulation of accruals. Journal of Accounting and Economics, 17(1-2), 145-176. https://doi.org/10.1016/0165-4101(94)90008-6

Denis, D. K. (2001). Twenty-five years of corporate governance research.pdf. Review of Financial Studies, 10(3), 191-212. https://doi.org/10.1016/S1058-3300(01)00037-4

Desai, H., Hogan, C. E., \& Wilkins, M. S. (2006). The Reputational Penalty for Aggressive Accounting: Earnings Restatement and Management Turnover. The Accounting Review, 81(1), 83-112. https://doi.org/10.2308/accr.2006.81.1.83

Efendi, J., Srivastava, A., \& Swanson, E. P. (2007). Why do corporate managers misstate financial statements? The role of option compensation and other factors. Journal of Financial Economics, 85, 667-708. https://doi.org/10.1016/j.jfineco.2006.05.009

Fama, E. F. (1980). Agency Problems and the Theory of the Firm. The Journal of Political Economy, 88(2), 288-307.

Firth, M., Rui, O. M., \& Wu, W. (2011). Cooking the books : Recipes and costs of falsi fi ed fi nancial statements in China, 17(535), 2010-2012. https://doi.org/10.1016/j.jcorp

Galasso, A., \& Simcoe, T. S. (2010). CEO Overconfidence and Innovation CEO Overconfidence and Innovation (November 2009).

GAO. (2002). Financial Statement Restatements:Trends, Market Impacts, Regulatory Responses, and Remaining Challenges. Financial Statement Restatements:Trends, Market Impacts, Regulatory Responses, and Remaining Challenges.

GAO, G. A. O. (2006). Financial Restatements: Update of Public Company Trends, Market Impacts, and Regulatory Enforcement Activities. Washington, D.C.: Government Printing Office, (July), 1-216. 
GAO, G. A. O. (2013). Internal Controls SEC Should Consider Requiring Companies to Disclose Whether They Obtained an Auditor Attestation. United States Government Accountability Office, (July).

Gervais, S., \& Goldstein, I. (2007). The positive effects of biased self-perceptions in firms. Review of Finance, 11(3), 453-496. https://doi.org/10.1093/rof/rfm022

Ghafran, C., \& O'Sullivan, N. (2017). The impact of audit committee expertise on audit quality: Evidence from UK audit fees. British Accounting Review, 49(6), 578-593. https://doi.org/10.1016/j.bar.2017.09.008

Gilson, S. C. (1989). Management turnover and financial distress. Journal of Financial Economics, 25(2), 241-262. https://doi.org/10.1016/0304-405X(89)90083-4

Gul, F. A., Khedmati, M., Lim, E. K. Y., \& Navissi, F. (2018). Managerial ability, financial distress, and audit fees. Accounting Horizons, 32(1), 29-51. https://doi.org/10.2308/acch-51888

Habib, A., Uddin Bhuiyan, B., \& Islam, A. (2013). Financial distress, earnings management and market pricing of accruals during the global financial crisis. Managerial Finance, 39(2), 155-180. https://doi.org/10.1108/03074351311294007

Hackbarth, D. (2008). Managerial Traits and Capital Structure Decisions, 43(4), 843-881.

Hasnan, S., Abdul Rahman, R., \& Mahenthiran, S. (2013). Management Motive, Weak Governance, Earnings Management, and Fraudulent Financial Reporting: Malaysian Evidence. Journal of International Accounting Research, 12(1).

Hasnan, S., \& Hussain, A. R. (2015, April). Factors associated with financial restatements: Evidence from Malaysia. Jurnal Pengurusan, 44.

Hasnan, S., Marzuki, H., \& Shuhidan, S. M. (2017). Effects of Board Characteristics on Financial Restatement in Malaysia. Pertanika Journal of Social Sciences \& Humanities, 25(S), 259-268.

Hennes, K. M., Leone, A. J., \& Miller, B. P. (2008). The importance of distinguishing errors from irregularities in restatement research: The case of restatements and CEO/CFO turnover. Accounting Review, 83(6), 1487-1519. https://doi.org/10.2308/accr.2008.83.6.1487

Hribar, P., \& Yang, H. (2010). Does CEO Overconfidence Affect Management Forecasting and Subsequent Earnings Management? Does CEO overconfidence affect management forecasting and subsequent earnings management?

Hribar, P., \& Yang, H. I. (2016). CEO Overconfidence and Management Forecasting, 204-227.

Hussain, A. R. M., Hasnan, S., \& Sanusi, Z. (2014). Accounting Misstatements and Monitoring Mechanisms : A Literature Review. Asia Pacific Journal of Accounting and Finance, 3(1), 33-43.

IFAC, I. F. of A. (2009). International Standard on Auditing 450: Evaluation of Misstatements Identified During the Audit. Evaluation of Misstatements Identified During the Audit, 368-379. Retrieved from http://www.ifac.org/system/files/downloads/a021-2010-iaasb-handbook-isa-450.pdf

Jensen, M. C., \& Meckling, W. H. (1976). Theory of the firm: Managerial behavior, agency costs and ownership structure. Journal of Financial Economics, 3(4), 305-360. https://doi.org/10.1016/0304-405X(76)90026-X

Khajavi, S., \& Dehghani, G. (2016). Board Characteristics and Managerial Overconfidence in an Emerging Market. International Journal of Economics and Financial Issues, 6(2), 529-537.

Khaliq, A., Motawe Altarturi, B. H., Mohd Thas Thaker, H., Harun, M. Y., \& Nahar, N. (2014). Identifying Financial Distress Firms : A Case Study of Malaysia's Government Linked Companies ( GLC ). International Journal of Economic, Finance and Management, 3(3), 141-150.

Koloub, M., \& Shoorvarzy, M. R. (2015). The Effect of Board Composition and CEO's Overconfidence in Earnings on Restatement of Financial Statements. European Online Journal of Natural and Social Sciences, 4(1), 1211-1218.

Lau, C. K., \& Ooi, K. W. (2016). A case study on fraudulent financial reporting: evidence from Malaysia. Accounting Research Journal, 29(1), 4-19. https://doi.org/10.1108/ARJ-11-2013-0084

Lomwel, G. Van. (2018). Does CEO-overconfidence affect firm performance? - The moderating impact of direct governance mechanisms and female representativeness, 1-70.

Malmendier, U., \& Tate, G. (2005). Does overconfidence affect corporate investment? CEO overconfidence measures revisited. European Financial Management, 11(5), 649-659. https://doi.org/10.1111/j.1354-7798.2005.00302.x

Malmendier, U., \& Tate, G. (2015). Behavioral CEOs: The Role of Managerial Overconfidence. Journal of Economic 
Perspectives, 29(4), 37-60. https://doi.org/10.1257/jep.29.4.37

Malmendier, U., Tate, G., \& Yan, J. (2011, October). Overconfidence and Early-Life Experiences: The Effect of Managerial Traits on Corporate Financial Policies Source. The Journal of Finance, 66(5), 1687-1733.

Merrienboer, G. Van. (2016). The Impact of CEO Overconfidence on Managerial Financial Reporting. Economics, $1-41$.

Mohamed Hussain, A. R., Mohd Sanusi, Z., Mahenthiran, S., \& Hasnan, S. (2016). Management Motives and Firm Financial Misstatements in Malaysia. International Journal of Economics and Financial Issues, 6(S4), 18-25.

Newman, P., Patterson, E., \& Smith, R. (2005). The Role of Auditing in Investor Protection. The Accounting Review, 80(1), 289-313.

Pandey, I. M. (2005). Financial Management. New Delhi: Vikas Publishing House PVT Ltd.

Park, J., \& Chung, C. Y. (2017). CEO overconfidence, leadership ethics, and institutional investors. Sustainability (Switzerland), 9(1), 1-28. https://doi.org/10.3390/su9010014

Persons, O. S. (1995). Using financial statement data to identify factor associated with fraudulent financial reporting. Journal of Applied Business Research.

Poretti, C., Schatt, A., \& Bruynseels, L. (2018). Audit committees' independence and the information content of earnings announcements in Western Europe. Journal of Accounting Literature, 40(January 2017), 29-53. https://doi.org/10.1016/j.acclit.2017.11.002

Presley, T. J., \& Abbott, L. J. (2013). AIA submission : CEO overconfidence and the incidence of financial restatement. Advances in Accounting, Incorporating Advances in International Accounting. https://doi.org/10.1016/j.adiac.2013.03.007

Purhanudin, N., \& Zakaria, Z. (2015). Managerial Overconfidence and Debt Maturity Structure of Malaysian Construction and Material Companies. Review of Contemporary Business Research, 4(1), 32-39. https://doi.org/10.15640/rcbr.v4n1a4

Romanus, R. N., Maher, J. J., \& Fleming, D. M. (2008). Auditor industry specialization, auditor changes, and accounting restatements. Accounting Horizons, 22(4), 389-413. https://doi.org/10.2308/acch.2008.22.4.389

Saieed, Z. (2016). Auditors find it tough to unmask corporate fraud. The Star Online, 1-6.

Schrand, C. M., \& Zechman, S. L. C. (2008). Executive Overconfidence and the Slippery Slope to Fraud. Chicago Booth School of Business Research Paper, (July 2007), 8-25. https://doi.org/10.1016/j.jacceco.2011.09.001

Schrand, C. M., \& Zechman, S. L. C. (2012). Executive Overconfidence and the Slippery Slope to Financial Misreporting. Journal of Accounting and Economics, 53(1-2), 311-329. https://doi.org/10.1016/j.jacceco.2011.09.001

Securities Commission Malaysia, S. (2018). SC's Public Statement: Multi Sports' retention of Lin Huozhi and Lin Liying as Executive Directors prejudicial to public interest.

Shibano, T. (1990). Assessing Audit Risk from Errors and Irregularities. Journal of Accounting Research, 28, 110-140.

Shleifer, A., \& Vishny, R. W. (1989). Management Entrenchment. Journal of Financial Economics, 25, 123-139.

Spathis, C. T. (2002). Detecting false financial statements using published data: some evidence from Greece. Managerial Auditing Journal, 17(4), 179-191. https://doi.org/10.1108/02686900210424321

Stunda, R. (2017). Financial Restatements By Industry and Their Market Impact. International Journal of the Academic Business World, 11(1), 49-56. Retrieved from http://search.ebscohost.com/login.aspx?direct=true \&db=bth\&AN=122825943\&site=ehost-live\&scope=site

$\mathrm{Su}$, L. D. (2010). Ownership structure, corporate diversification and capital structure. Management Decision, 48(2), 314-339. https://doi.org/10.1108/00251741011022644

Ting, I. W. K., Lean, H. H., Kweh, Q. L., \& Azizan, N. A. (2016). Managerial overconfidence, government intervention and corporate financing decision. International Journal of Managerial Finance, 12(1), 4-24.

Verschoor, C. C. (2014, March). Penalties for Fraud Are Insufficient to Deter. Strategic Finance.

Wahab, E. A. A., Gist, W. E., \& Majid, W. Z. N. A. (2014). Characteristics of non-audit services and financial restatements in Malaysia. Journal of Contemporary Accounting and Economics, 10(3), 225-247. 
https://doi.org/10.1016/j.jcae.2014.10.001

Watts, R. L., \& Zimmerman, J. L. (1981). The Markets For Independence and Independent Auditors.

Wei, I., Ting, K., Azlinna, N., Azizan, B., \& Long, Q. (2015). Upper Echelon Theory Revisited: The relationship between CEO Personal Characteristics and Financial Leverage Decision. Procedia - Social and Behavioral Sciences, 195, 686-694. https://doi.org/10.1016/j.sbspro.2015.06.276

Wruck, K. H. (1990). Financial distress, reorganization, and organizational efficiency. Journal of Financial Economics, 27(2), 419-444. https://doi.org/10.1016/0304-405X(90)90063-6

Yasar, A. (2013). Big Four Auditors' Audit Quality and Earnings Management: Evidence from Turkish Stock Market. International Journal of Business and Social Science, 4(17), 153-163.

Zahn, J.-L. W. M. Van der, \& Tower, G. (2004). Audit committee features and earnings management: further evidence from Singapore. International Journal of Business Governance and Ethics, 1(2,3), 233-258. https://doi.org/10.1504/IJBGE.2004.005257

Zalata, A. M., Tauringana, V., \& Tingbani, I. (2018). Audit committee financial expertise, gender, and earnings management: Does gender of the financial expert matter?. International Review of Financial Analysis, 55(October 2017), 170-183. https://doi.org/10.1016/j.irfa.2017.11.002

Zanani, W., \& Abdullah, W. (2008). The Impact of Board Composition, Ownership and CEO Duality on Audit Quality: The Malaysian Evidence. Malaysian Accounting Review, 7(2), 17-28.

Zhao, Q., \& Ziebart, D. A. (2017). Consequences of CEO Overconfidence. Accounting and Finance Research, $6(2), 94$. https://doi.org/10.5430/afr.v6n2p94

Zhizhong, H., Juan, Z., Yanzhi, S., \& Wenli, X. (2011). Does corporate governance affect restatement of financial reporting? Evidence from China. Nankai Business Review International, 2(3), 289-302. https://doi.org/10.1108/NBRI-04-2016-0013

Zhou, F., Zhang, Z., Yang, J., Su, Y., \& An, Y. (2018). Delisting pressure, executive compensation, and corporate fraud: Evidence from China. Pacific Basin Finance Journal, 48(August 2017), 17-34. https://doi.org/10.1016/j.pacfin.2018.01.003 